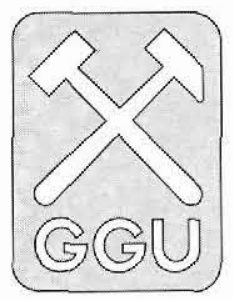

\title{
Mineral resource activities 1993: spectrum of research and services
}

\author{
Hans Kristian Schønwandt
}

The Geological Survey of Greenland (GGU) has over the past few years improved its service to the mineral industry, not only by streamlining access to basic geological, geophysical and geochemical data, but also by increased effort in informing the mineral industry about available geodata. In recent issues of Report of Activities several papers discuss the nature of relevant geodata (Schønwandt 1990, 1993), and Dawes (this report) has summarised GGU's data service in its present form.

Informing the mineral industry about Greenland's exploration potential has also seen expansion. This has included promotion at annual conventions and trade shows in North America and Europe (Dawes et al., 1993; Dawes, this report), and the launching of Greenland MINEX News (Greenland Mineral Exploration Newsletter) which intends to give an up-date on geological and legislatory information and also on data services from GGU (Dawes \& Thomsen, 1993). Finally, excursions for the international mining industry have been arranged in order to familiarise the exploration community with Greenland geology and field conditions as well as the logistic capacity of the island (Dawes et al., 1993).

\section{Drilling activity}

Some may judge it to be too early to assess the overall effect of the promotion and contact initiatives towards industry outlined in the above, but it can be said that Greenland has seen an increase in recent years in the amount of exploration dollars used in spite of the worldwide decrease in exploration activity. For the first time since the 1970 s, four major drilling programmes were carried out during the 1993 field season: by Falconbridge Greenland A/S, Nunaoil A/S, Cyprus Greenland Corporation and Platinova $\mathrm{A} / \mathrm{S}$.

On the island of Disko (Fig. 1) Falconbridge Greenland A/S drilled for Norilsk-type mineralisation in shallow intrusives of the Tertiary basalt province; Nunaoil A/S's target was base metal bearing massive sulphides in the Archaean greenstone belt at Sermiligaarsuk (Fig. 1); and Cyprus Greenland Corporation drilled a high-grade lode gold occurrence hosted in Lower Proterozoic greenstones at Kirkespirdalen in South Greenland (Fig. 1). The results from these three diamond drill programmes are still pending, but Platinova $\mathrm{A} / \mathrm{S}$ has issued a press release on the first season of exploration on their zinc discovery in Peary Land at Citronen Fjord in North Greenland (Fig. 1). The deposit is a bedded sulphide occurrence hosted in black shales within a second order sedimentary basin along the

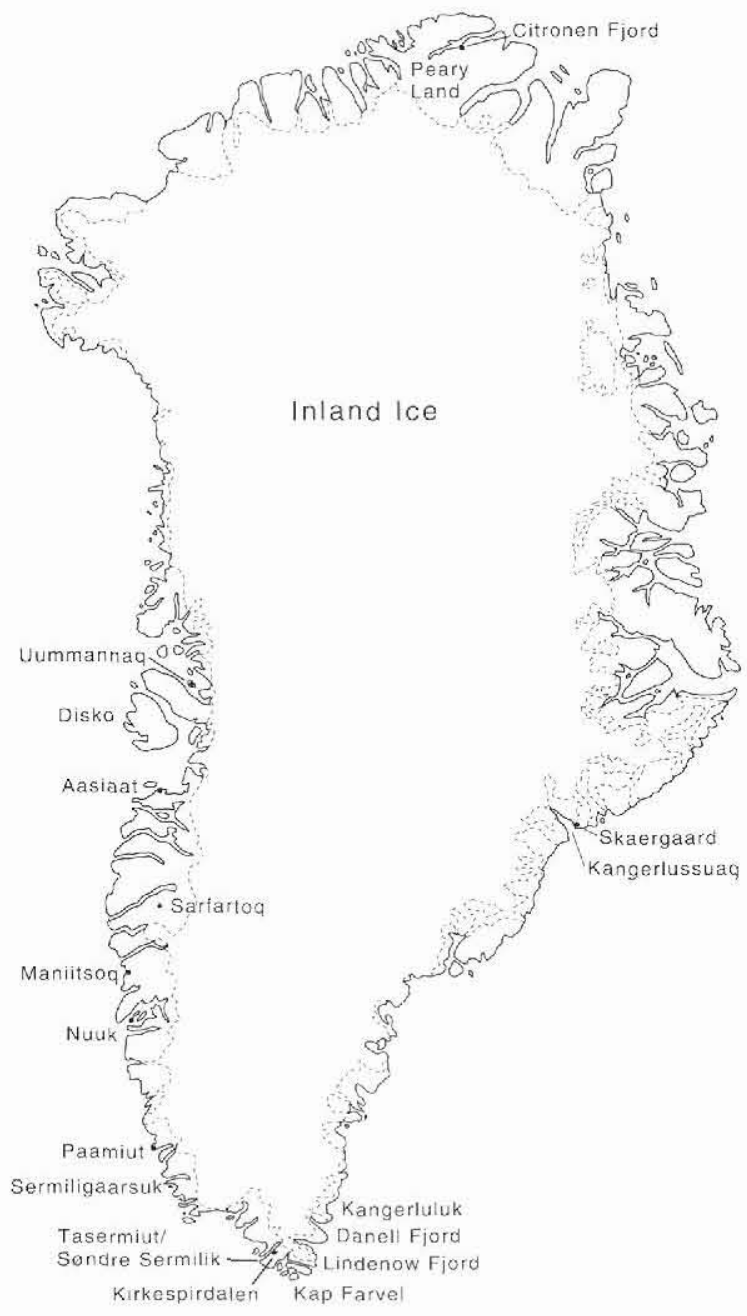

Fig. 1. Map of Greenland showing localities mentioned in text. 


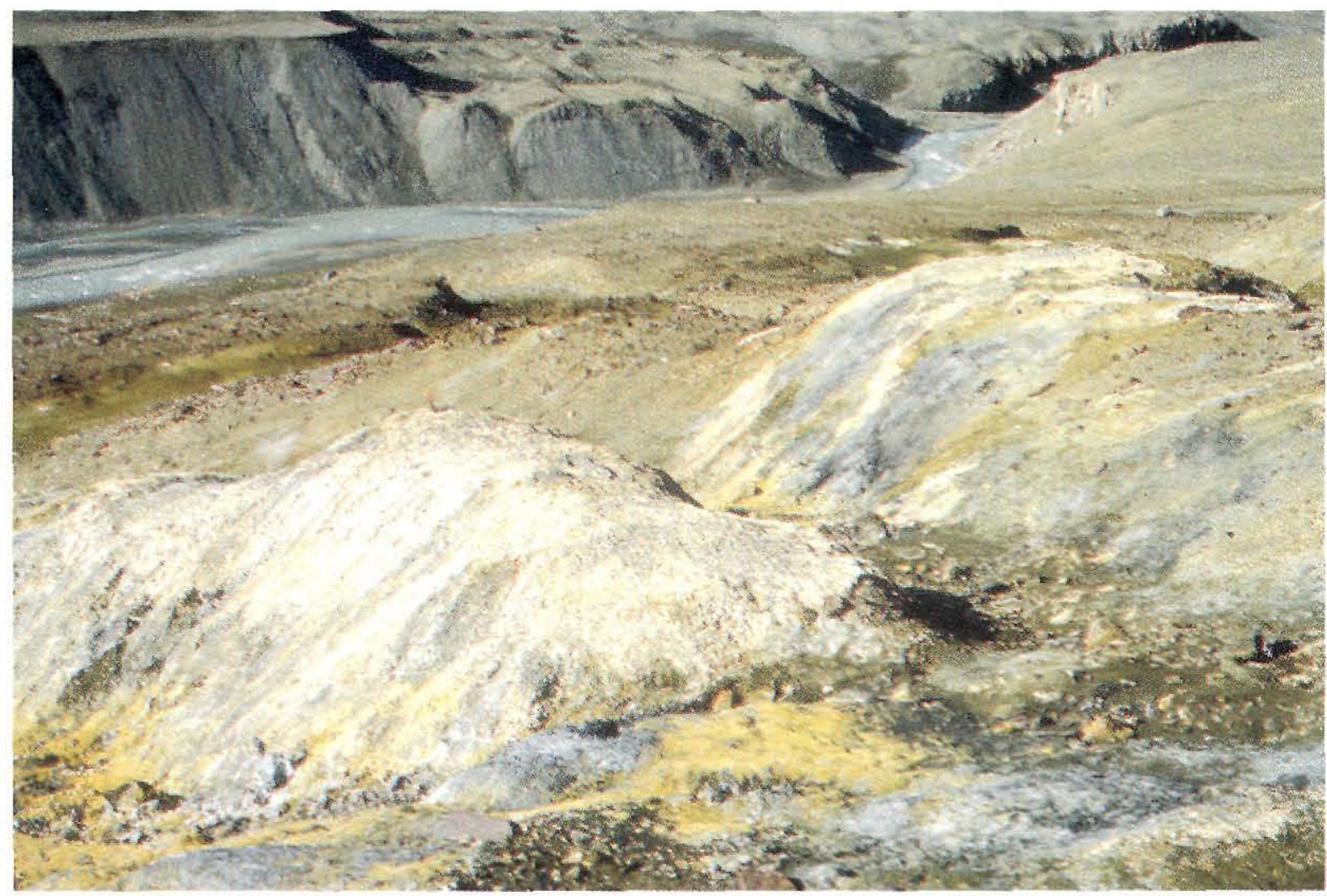

Fig. 2. One of the giant gossans in the Citronen Fjord area discovered by Platinova A/S in 1992. Note the person on top of the gossan.

Navarana Fjord escarpment. The escarpment separates platform carbonates to the south from deep-water siliciclastic trough sediments to the north. In the discovery area sulphide beds are exposed over a strike length of $1200 \mathrm{~m}$ and have thicknesses of up to $26 \mathrm{~m}$ (Fig. 2). Geophysical surveys indicate a large, conccaled target $2500 \mathrm{~m}$ north-west of the discovery area.

Drill-hole testing by Platinova A/S of the discovery area showed mineralised intervals between $10 \mathrm{~m}$ and $30 \mathrm{~m}$ thick yiclding $3-4 \% \mathrm{Zn}$ and about $1 \% \mathrm{~Pb}$; however, highgrade sections were in the order of $2 \mathrm{~m}$ to $3 \mathrm{~m}$ returning $7-12 \% \mathrm{Zn}$ and $2-5 \% \mathrm{~Pb}$. Two drill holes tested the concealed target $2500 \mathrm{~m}$ north-west of the discovery area. Here two mineralised levels were intercepted, the upper with a thickness of about $30 \mathrm{~m}$ and the lower $50 \mathrm{~m}$ thick. The upper level is thought to correlate with the sulphides in the discovery area. The best mineralised section was $2.7 \mathrm{~m}$ thick and yielded $10.9 \% \mathrm{Zn}$ and $0.5 \% \mathrm{~Pb}$.

Platinova A/S has demonstrated the occurrence of bedded sulphides in a geological setting which classifies the deposit as a platform margin, stratiform sulphide deposit. This environment is known to host some of the world's largest zinc deposits. Platinova $\mathrm{A} / \mathrm{S}$ is preparing a minimum $8000 \mathrm{~m}$ drill programme for 1994.

\section{Research activity}

GGU's activities within the field of mineral resources cover a spectrum of research subjects including mineral assessment of the Ketilidian orogen in South Greenland (Project SUPRASYD), regional geochemical mapping, the dispersion pattern of kimberlite indicator minerals, regional lead-isotope studies and detailed investigations of the gold-palladium reef in the Skaergaard intrusion.

\section{Project SUPRASYD}

This project was initiated in 1992 in order to reassess the geology of the Lower Proterozoic Ketilidian orogen and its mineral potential; a region known to contain supracrustal rocks and regional geochemical anomalies. Field work in 1992 focused on the east coast of South Greenland (Nielsen et al., 1993). One of the main conclusions is that a substantial part of the region between Kangerlyluk and Lindenow Fjord (Fig. 1) is underlain by psammitic and semipelitic rocks in various stages of gneissification and that these rocks resemble the metasedimentary rocks on the west coast of South Greenland in the Tasermiut Søndre Sermilik area, some $50 \mathrm{~km}$ distant across the 
Inland Ice (Fig. 1). The geological similarity between the two areas is also reflected by the regional stream sediment geochemistry. The gold anomalous area around Tasermiut -Søndre Sermilik has its counterpart in the area between Lindenow Fjord and Danell Fjord, but so far bedrock gold mineralisation equivalent to the high grade, lode gold occurrence of Tasermiut - Søndre Sermilik (found by Nunaoil A/S; Gowen et al., 1993) has not been discovered. Uranium and tungsten anomalies (Steenfelt et al., 1992) are also common to the two areas.

The geochemical data also indicates that the southern part of the Julianehåb batholith is part of the gold anomalous area, and field work was carried out here in 1993 (Chadwick et al., in press; Garde \& Schønwandt, this report). One of the interesting results of this work, from a metallogenetic point of view, was the discovery of several regional shear zones. The shear zones were formed during $P-T$ conditions of mid'dle amphibolite to lower greenschist facies, and are characterised by widespread hydrothermal activity, especially in the form of quartz veining. It can be speculated that the gold anomalous area in South Greenland is caused by two different types of gold mineralisation: lode gold deposits hosted in the supracrustal sequence, and shear zone related gold mineralisation hosted by the Julianehåb batholith. Ongoing research and further field work will try to clarify these problems and their metallogenetic consequences.

\section{Geochemistry}

GGU's regional geochemical mapping programme is aimed at delineating geological provinces and metallogenic regions. The programme started in South Greenland as part of a regional uranium exploration survey (Armour-Brown et al., 1983). Subsequently systematic stream sediment sampling has been carried out by the Survey, and during the 1993 field season 660 samples were collected in the region around Paamiut, Maniitsoq and Aasiaat in West Greenland (Fig. 1). This sampling completed the coverage of the Precambrian areas of West Greenland between Kap Farvel and Uummanaq $\left(60^{\circ}-70^{\circ} 30^{\prime} \mathrm{N}\right)$ (Steenfelt, this report). In addition 230 samples were collected in North-East Greenland in connection with regional geological mapping (Henriksen, this report).

The results of the 1993 geochemical surveys will be reported as they become available in GGU's Open File Series. The geochemical data from West and South Greenland will be used for regional compilations, and will be published together with geophysical, lithological and mineral occurrence maps in future numbers of GGU's Thematic Map Series.

\section{Kimberlite indicator minerals}

Kimberlites have been known to occur in Greenland for several decades, and more than 500 occurrences have now been documented (Larsen, 1991). The West Greenland kimberlite province stretches for $1300 \mathrm{~km}$, and is characterised mainly by dykes and sheets, although a few diatremes of kimberlite are also known. The majority of kimberlites occur in the southern part of the province within the Archaean block.

Only scattered prospecting for diamonds has been carried out by a few companies, and a single micro-diamond was found as a result of this exploration effort. Recent research has shown that the West Greenland kimberlites originated within the diamond stability field (Larsen \& Rønsbo, 1993), indicating that the province could have diamond potential.

Of vital importance for diamond exploration is knowledge of the dispersion pattern of indicator minerals. A pilot project has been initiated to investigate this pattern in order to help industry in designing the most efficient exploration technique under the current physiographic conditions of West Greenland. Due to the lack of extensive moraine cover the investigation of the dispersion pattern has focused on river transportation of indicator minerals. The main area studied is at Sarfartoq where known kimberlite dykes and sheets are drained by streams. In both high and low-energy streams samples of about $45 \mathrm{~kg}$ of gravel have been collected at each sample site. The material was sieved in order to establish the size distribution of the indicator minerals, and the samples also give an indication of the distribution of the indicator minerals along the longitudinal profile of each stream. Laboratory results are pending and will be published in an Open File Report.

\section{Lead-isotope studies}

Regional lead-isotope studies have been initiated to address the provenance of lead in mineral occurrences with the aim of contributing to the characterisation and resource evaluation of metallogenetic provinces. Three projects are in progress, dealing with different types and ages of mineralisations.

One project is focused on mineral occurrences in East and North-East Greenland $\left(70^{\circ}-74^{\circ} \mathrm{N}\right.$ and $\left.76^{\circ}-78^{\circ} \mathrm{N}\right)$, and in the Kangerlussuaq area of South-East Greenland $\left(68^{\circ} \mathrm{N}\right.$; Fig. 1). This regional study covers mineralisations ranging in age from Lower Proterozoic to Tertiary. Different types of mineralisation occur and the characteristic ranges of lead isotope ratios have been identified. Isotopic 'fingerprints' have been used in evaluation of the crustal source of lead (Jensen, 1993a, b). 
A second study concerns base metal mineralisation within the Jameson Land basin of central East Greenland. Geological and lead isotope investigations have included both sulphide mineral occurrences and possible source rocks for the lead within and adjacent to the sedimentary basin, and will be used in detailed mapping of mobilisation, transportation and deposition of lead.

Finally, a lead isotope investigation of mineralisation hosted in Archaean and Lower Proterozoic rocks in the Disko Bugt area is focused on source and age problems of lead in these spatially closely related occurrences.

\section{Skaergaard intrusion}

The discovery of a gold-palladium reef in the Skaergaard intrusion by Platinova A/S in 1987 (Nielsen, 1990; Nielsen \& Schønwandt, 1990) prompted the wish for a detailed investigation of the mineralisation. This research project is carried out in cooperation with the Geological Institute at the University of Copenhagen and comprises the following sub-projects:

(a) general description of the mineralisation;

(b) petrographic investigation of the mineralisation including the mineral chemistry and petrography of the host rock and of the ore mineral assemblages;

(c) experimental investigations of $\mathrm{Pd}, \mathrm{Pt}$ and $\mathrm{Au}$ doped melts in the $\mathrm{Cu}-\mathrm{Fe}-\mathrm{S}$ system.

Preliminary investigations show the mineralisation to consist of at least 10 distinct units concordant with the layering in the host rocks (Nielsen \& Gannicott, 1993). The structure of the mineralisation can best be described as a stack of concordant discs of decreasing upwards diameter separated by weakly mineralised gabbro. Each layer is chemically distinct and in three dimensions the mineralisation shows a fractionation of platinum, palladium and gold. Gold is enriched away from the centre of the intrusion, as reflected in the enrichment in the rims of each disc and in the uppermost disc. Preliminary results of the experiments suggest the mineralisation formed at $c .900^{\circ} \mathrm{C}$ by fractionation of PGM and Au phases from immiscible sulphide melts capable of dissolving at least $10 \%$ gold (Makovicky et al., 1993).

\section{References}

Armour-Brown, A., Steenfelt, A. \& Kunzendorf, H. 1983: Uranium districts defined by reconnaissance geochemistry in South Greenland. J. Geochem. Expl. 19, 127-145.

Chadwick, B., Erfurt, P., Frisch, T., Frith, R. A., Garde, A. A., Schønwandt, H. K., Stendal, H. \& Thomassen, B. in press: Sinistral transpression and hydrothermal activity during emplace- ment of Early Proterozoic Julianehåb batholith: field work in the area adjacent to Søndre Sermilik, South Greenland. Rapp. Gronlands geol. Unders.

Dawes, P. R., Schønwandt, H. K. \& Thomassen, B. 1993: Greenland mineral resource information to industry: increased scope in 1992. Rapp. Gronlands geol. Unders. 159, 18-21.

Dawes, P. R. \& Thomsen, H. H. 1993: Greenland MINEX News: a new service for the mining industry. Rapp. Gronlands geol. Unders. 159, 16-18.

Gowen, J., Christiansen, O., Grahl-Madsen, L., Pedersen, J. \& Robyn, T. L. 1993: Discovery of the Nalunaq gold deposit Kirkespirdalen, SW Greenland. In Romberger, S. B. \& Fletch$\mathrm{er}, \mathrm{D} . \mathrm{I}$. (ed.) Conference on integrated methods in exploration and discovery. AB40-AB41. Extended abstract, Denver, CO, April 1993.

Jensen, S.M. 1993a: Lead isotope studies on mineral showings and ore deposits in East Greenland. Rapp. Grønlands geol. Unders. 159, 101-108.

Jensen, S.M. 1993b: Lead isotope composition of stratabound Cu$\mathrm{Pb}-\mathrm{Zn}$-Ba occurrences in Upper Palaeozoic - Mesozoic sediments in East Greenland. In Fenoll Hach-Alí, P., Torres-Ruiz, J. \& Gervilla, F. (ed.) Current research in geology applied to ore deposits, 327-330. Granada: Universidad de Granada.

Larsen, L. M. 1991: Occurrences of kimberlite lamproite and ultramafic lamprophyres in Greenland. Open File Ser. Gronlands geol. Unders. 91/2, $36 \mathrm{pp}$.

Larsen, L. M. \& Rønsbo, J. 1993: Conditions of origin of kimberlites in West Greenland: new evidence from the Sarfartoq and Sukkertoppen regions. Rapp. Gronlands geol. Unders. 159, 115-120.

Makovicky, E., Makovicky, M. \& Rose-Hansen, J. 1993: Skaergaard mineralization in a test tube: first results. Abstract supplement No. 3. Terra Nova 5, 31 only.

Nielsen, T. F. D. 1990: A gold mine in East Greenland? Rapp. Grønlands geol. Unders. 148, 40-43.

Nielsen, T. F. D. \& Gannicott, R. A. 1993: The Au-PGM deposit of the Skaergaard intrusion, East Greenland. Abstract supplement No. 3 Terra Nova 5, 38 only.

Nielsen, T. F. D. \& Schønwandt, H. K. 1990: Gold and platinum group metal mineralisation in the Skaergaard intrusion, southern East Greenland. Rapp. Grønlands geol. Unders. 148, 101103.

Nielsen, T. F. D., Chadwick, B., Dawes, P. R., Frith, R. A. \& Schønwandt, H. K. 1993: Project SUPRASYD 1992: Opening season in the Ketilidian of South Greenland. Rapp. Grønlands geol. Unders. 159, 25-31.

Schønwandt, H. K. 1990: Activities within the field of mineral resources. Rapp. Grønlands geol. Unders. 148, 37-40.

Schønwandt, H. K. 1993: GGU Open File Series: a review of reports related to Greenland mineral exploration. Rapp. Grønlands geol. Unders. 159, 22-24.

Steenfelt, A., Dam, E. \& Nielsen, J. P. 1992: Reconnaissance geochemical exploration of map sheet $68 \mathrm{~V} 2\left(67^{\circ} 55^{\prime}\right.$ to $68^{\circ} 45^{\prime} \mathrm{N}$, $50^{\circ} 15^{\prime}$ to $52^{\circ} 45^{\prime} \mathrm{W}$ ), West Greenland. Open File Ser. Gronlands geol. Unders. 92/7, $14 \mathrm{pp}$.

H. K. S., Geological Survey of Greenland, Copenhagen 